\title{
Missions of Patriotism: Joseph H. Jackson and Martin Luther King
}

\section{Sam Hitchmough}

\section{(2) OpenEdition \\ Journals}

Electronic version

URL: https://journals.openedition.org/ejas/9155

DOI: $10.4000 /$ ejas. 9155

ISSN: 1991-9336

Publisher

European Association for American Studies

\section{Electronic reference}

Sam Hitchmough, "Missions of Patriotism: Joseph H. Jackson and Martin Luther King", European journal of American studies [Online], 6-1 | 2011, document 3, Online since 23 June 2011, connection on 08 July 2021. URL: http://journals.openedition.org/ejas/9155 ; DOI: https://doi.org/10.4000/ejas.9155

This text was automatically generated on 8 July 2021 .

Creative Commons License 


\title{
Missions of Patriotism: Joseph $\mathrm{H}$. Jackson and Martin Luther King
}

\author{
Sam Hitchmough
}

\section{I.Introduction}

1 Joseph $\mathrm{H}$. Jackson has been treated very negatively in history-writing. Most texts refer to him in passing as the "brilliantly conservative", "autocratic" president of the National Baptist Convention, a figure opposed to the Civil Rights Movement or else a man with a personal grudge or a neurotic dislike of Martin Luther King. ${ }^{1}$ King's deputy, Ralph Abernathy, speculates that it may have been a "certain amount of envy" that caused Jackson to 'turn' on the movement. ${ }^{2}$ The bitter feud cut so deep that when Chicago city council, months after King's assassination, decided to change the name of South Parkway, the street on which his Olivet Baptist Church stood, to Martin Luther King Boulevard, Jackson reacted to the prospect by altering the main entrance and address of the church so as to avoid any association with King's name. ${ }^{3}$

Despite this reputation, Jackson requires further consideration for a number of reasons. He became pastor at Olivet Baptist Church in Chicago in 1941, the largest African American congregation in America, and assumed further significance when he was elected President of the National Baptist Convention in 1953, a group of some six million people, the largest organisation of black people in the world. Sociologist E. Franklin Frazier contended that being president of the NBC, the largest black religious organization in the world, was comparable to being the black president of the United States, whilst historian Taylor Branch refers to him as the "Negro Pope" and suggests that Jackson was "considered a prince of the national Negro church." ${ }^{4}$ The scant attention paid to him has not allowed for one of King's most ardent detractors to be heard alongside the more usual critics such as Roy Wilkins of the National Association for the Advancement of Colored People, Malcolm X, or activists from the Student Nonviolent Co-ordinating Committee or Black Power groups. Nor has it allowed an 
appreciation of a vibrant ideological debate about the nature of black patriotism and the shape of civil rights protest that emerged between Jackson and King.

Born in Mississippi in 1900 and experiencing a hard life as a farm hand, Jackson was ordained as a Baptist minister at the age of 22, and his first congregation was in Macomb, Mississippi. Experiencing the institutional racism of the Jim Crow system, Jackson went on to construct a racial philosophy that he felt represented the most appropriate and effective response to the environment, consisting of self-help, perseverance and a belief in, and loyalty to, the 'system'. Jackson believed in self-help as a means for individual rather than collective improvement This blended a faith in law and order, patriotism (a brand of), a disinclination toward direct action protest, and is a response not dissimilar to that of the turn of the century black leader Booker T.Washington, who counselled black southerners to work hard and gradually attain equality through a strategy of non-confrontation and a demonstration of loyalty.

The strength and distinctiveness of Jackson's conservative philosophy and his individualistic 'bootstraps' patriotism stood at a fascinating, and peculiarly angled, opposite to the more collective and embracing patriotism of Martin Luther King. This paper discusses the two men's differing views on patriotism and explores how their patriotisms affected conceptualisations of the civil rights movement. ${ }^{4}$

\section{Polarisation}

5 King's patriotism was a largely non-consensual patriotism, a belief that derived its energy and focus from a faith in the universal impulses and collective embrace of the founding documents. Jackson planted his patriotism firmly within a more consensual civic framework that revolved heavily around concepts of individualism, meritocracy and materialism, more the 'official' narrative of patriotism.

Both men were both activists who used patriotism to actively probe the national conscience, sought to have the promises of the Constitution and the Declaration of Independence fulfilled, to resolve the cultural, social and historical problems of being 'disinherited. ${ }^{5}$ Both saw equality as an incomplete quest and that the answer lay within a truer observance of the American creed. "This American venture" observed Jackson in 1964 "is powerful but not perfect; ever growing but not grown; and still becoming, but not yet complete." Both were strongly patriotic, steeping their speeches in American rhetoric with multiple references to the nation's history and symbols. But they differed in how patriotism would best serve this quest for equality, and how the movement would best serve a sense of patriotism. It was also a question of which strand of patriotism would be employed; an absolute confidence in the official patriotism of the 'system' that needed a push along the road to fruition, or a reform patriotism that sought to unlock and popularise communal and collective values that had too often been merely inherent within the American creed. The similarities and differences between the two men are intriguing and underexplored, and contribute to a fuller understanding of the relationship between patriotism and activism.

The stage for their ideological confrontation was Chicago. King and his organisation, the Southern Christian Leadership Conference (formed in 1957), aimed to use the city as a springboard for launching civil rights campaigns in the north after a decade of increasingly successful activism in the southern states that had culminated in the Civil Rights Act and Voting Rights Act in 1964 and 1965. The Chicago campaign that started 
in 1966 and became SCLC's longest endeavour at 20 months, acts as a vehicle for this conflict and Jackson's opposition to King became one of the many factors contributing to the de-railing of the city-wide movement and the widely held perception that the Chicago campaign was a failure. Jackson's position within Chicago at this time is indicative of the huge complexities of mounting a campaign within the city, highlighting SCLC's internal disagreements and mistakes, as well as the problems that the movement had in mobilising not just participation from black churches, many of which Jackson blocked access to, but more broadly across the black community. But it is Jackson's relationship to Mayor Daley's infamous city machine where his loyalty to authority and a law and order philosophy struck a chord with city-wide efforts to counter King's protests, throwing the differences between the two men's application of patriotism to the struggle into sharp relief. The philosophical similarities and variations between Jackson, King and notions of patriotism form part of a deeply important intellectual debate about different African-American standpoints and options that played out not just in Chicago but have national repercussions.

The often discussed friction between the two men is most clearly and openly seen to start when the National Baptist Convention ruptured in 1961, leading to the breakaway Progressive National Baptist Convention, Inc. that included King. ${ }^{7}$ Prior to this, Jackson had in fact lent some support to the young King's activity in Montgomery some years before. In March 1956, he wrote offering his support for King's "heroic struggles", enclosing two checks for $\$ 1,000$, one from the National Baptist Convention and one from his own Olivet congregation in Chicago. According to Martin Luther King, Sr., who had helped Jackson to secure the presidency a few years beforehand, he had even offered to buy a bus for the boycotters to assist with the car pooling system. ${ }^{8} \mathrm{Jackson}$ was, in addition, present at the Montgomery Improvement Association's 'Institute on Non-violence and Social Change' in December 1956 with fellow Chicagoan, gospel singer Mahalia Jackson. Further back still, Jackson had at one point lived with the King family during a Baptist convention and returned "frequently as a houseguest in later years." Taylor Branch continues by observing that "young M.L. knew and revered Jackson from the time he was ten years old" ${ }^{9}$ However, when King addressed the September 1956 National Baptist Convention meeting in Denver, there were calls from at least two ministers calling for King to seek election and unseat Jackson. Whilst there were open concerns about Jackson's manoeuvring to lengthen his tenure as president, there was also a sense amongst many that Jackson was too conservative to react to the growing pace of activism. A panel discussion at the convention in fact debated what quickly became a critical question: 'National Baptists Facing Integration: Shall gradualism be applied?' After the debate, King delivered his sermon, 'Paul's Letter to American Christians', to a rapturous response. Jackson's prickly reaction was that "we must not crown our heroes too quickly." ${ }^{10}$ Jackson's increasingly robust defence of his tenure included a suit brought against him by rival presidential candidate Gardner C.Taylor from Brooklyn with a group that included both King Sr., and Jr., concerned about the constitutionality of his NBC presidency, and conventions that often broke out into physical violence. This confirmed the opinion of many that in its present form the NBC would not be an effective or active body in the civil rights movement.

By 1957, Taylor Branch argues that Jackson had become increasingly autocratic and that he was determined to "consolidate power against active involvement in civil rights." ${ }^{11}$ By 1961, Jackson had begun to speak out against the 1960 student sit-ins and the mounting movement, alienating many of the younger ministers in the Convention, 
leading more to look to King to encourage a more progressive and tolerant attitude toward civil rights. Jackson would later reflect that King's Southern Christian Leadership Conference "began to throw its influence and strength against the functional responsibilities of the just laws of the land and courts..." ${ }^{12}$ The September 1961 Kansas City convention became the site of an inevitable run-in between the 'old' and 'new' orders played out through the leadership bid of Reverend Gardner C.Taylor, a civil rights advocate and personal friend of King. What unfortunately occurred on September $6^{\text {th }}$, however, contributed significantly to the personal feuding and illfeeling that ensued between King and Jackson. Amid the rising chaos at the convention, with the groups competing for the podium, Reverend Arthur Garfield Wright, a Jackson supporter from Detroit, was knocked from the platform and later died from his injuries. Jackson subsequently won the election and then "tried to lay the blame for Wright's death on those who had supported his opponent." Branch and Garrow both detail how Jackson claimed King had been the hand behind Taylor's bid for leadership and had "masterminded the invasion of the convention floor...which resulted in the death of a delegate."At the funeral in Detroit, Jackson alluded to King as one of a new breed of "hoodlums and crooks in the pulpits today." 13 King was removed from office (vice president of the NBC's Sunday School Board) and the schism resulted in the establishment of the breakaway Progressive National Baptist Convention, with around a half million members. ${ }^{14} \mathrm{Jackson}$ held onto the reins of the NBC and in doing so thwarted what Branch and Wallace Best argue was King's ambitious plan to co-opt the NBC and use its immensely powerful national infrastructure as a potent force for civil rights, "an institutional basis for the civil rights movement." ${ }^{15}$ As Branch points out, it was a ready-made "civil rights phalanx that could spring on a target upon demand." ${ }^{16}$ It was also, as Best suggests, a "struggle over the very nature of the work of black Baptist churches in the public mind." ${ }^{17}$ Jackson ended up standing "as a colossus against all King's hopes of using the organised national church in the civil rights movement." ${ }^{18}$

Histories rarely venture beyond this rift. Best contends that "scholars have misinterpreted and, therefore, undervalued the conflict" between the two men. It was not, he argues, "a struggle between conservative and progressive forces within the NBC .... Their conflict was essentially religious in nature and was predicated on questions regarding what constituted church work among black Baptists." ${ }^{19}$ This distinction helps to better understand their dynamic and its importance but it is not the only essential factor. Best also suggests that "Jackson and King were not ideological polar opposites" and this is certainly true..$^{20} \mathrm{~A}$ fuller and deeper appreciation still comes from seeing that their conflict was a clash of patriotisms, both at a conceptual level and its application to civil rights. Their patriotisms identified the same problems, had the same goal, the same rhetorical strategies, but represented fundamentally different beliefs in how patriotism was to be wielded as a device for progress, how patriotism could be most effectively employed to garner wider support.

\section{Chicago}

Their paths crossed again as Martin Luther King and the SCLC gathered to move north to Chicago, home to Jackson. King not only faced the disorientating tactics of accommodation played by the wily Mayor Richard J.Daley, who had been in office since 1955 , but he was faced with potential structural and organisational difficulties as the 
religious constituency that King and followers could frequently rely on for some support was, in large part, influenced by Jackson who had close links with the city administration, and was strongly opposed to marching and other forms of 'disruptive' protest. Nicholas Lemann suggests that Jackson was one of a number of black religious leaders in the city who had longstanding and complex relationships with the machine involving patronage, loyalty and favours whilst Ralph Abernathy recalled that Jackson was one of the few black people in Chicago who could be called an insider, a part of the Daley machine."21

Reverends Jesse Jackson and Clay Evans recalled a 1966 meeting at True Light Baptist Church at which "the host minister (Bill Paxton) went to his office and got his pistol" once preachers like Evans pressed the group to consider a vote allowing King to speak in Chicago with the group's support." Jackson commented on a "strong undercurrent of ministers against (King) being here." 22

13 Jackson had, for example, been happy to speak at the National Association for the Advancement of Colored People convention in Chicago in 1963 alongside the mayor who was subsequently jeered off stage whilst in the middle of what Jackson referred to as a "most courageous, effective, and patriotic speech." Indeed, Jackson claimed that "by any stretch of the imagination no one could classify Mayor Richard J.Daley with the enemies of freedom" having "by his deeds proven himself to be a friend of civil rights and a devout supporter of the NAACP." He went on to implicitly associate the NAACP, his own NBC and Daley as a group of associations and leaders who had joined together "in the interest of a better America and the continuing growth of human freedom." Additionally, Jackson had warm words for schools superintendent Benjamin Willis, the "fine citizens of Chicago dedicated to the American ideal of first class citizenship" who sat on the Board of Education (all targets of a large, well-organised civil rights campaign against Chicago school segregation) On top of this, he also praised the existing governmental civil rights agencies in the city ( 16 of them in total) which were collectively committed to "implement the promises of the Federal Constitution and the dreams of all American citizens for full rights and equality of opportunity in every phase of the city's life" and which were deemed inadequate by civil rights activists. He also had good words for the black aldermen who had been "duly elected from their respective wards and assigned the responsibility of helping to unite the laws of the city...and to help in the affairs of government in general and citizen's welfare in particular." ${ }^{23}$ These six black aldermen across the city were dubbed the 'Silent Six' for their steadfast silence on civil rights issues, owing their position to Mayor Daley's patronage. Jackson believed that existing institutions and existing personnel would, given due process, best fulfil the American Dream for all. Given time, the system would work. Civil rights protest and agitation, he reasoned, were disruptive, unreasonable and counter-productive.

Jackson was thus one of the factors behind the disappointingly low turnout for the Illinois Civil Rights rally at Soldier Field intended to kick-start protest in the city. Not an advocate of such mass rallies he used his churches in the city to urge people to stay away. His opinion is revealed when he later commented that "twenty odd thousand people gathered..." and that "songs, speeches, statements, and appeals finally led to deeper feelings of bitterness, anxiety, and frustration." There certainly appears to have been a South Side church coalition against King and Mahalia Jackson played a part in attempting to dilute it, personally intervening and asking Mayor Daley for assistance in 
locating a suitable venue for King to speak as a group of churches would not play host to him..$^{24}$ Jackson was a "creator of order, one who, in times of crisis, would step forward and tell his congregation and the black community at large that they must obey the law and accept the role the Daley machine had allotted to them." ${ }^{25}$

Jackson opposed the introduction of civil rights campaigning in the city but just as importantly he opposed King. David Garrow writes that as "much as King was seen as a threat to the 'old order' in civil rights, namely Roy Wilkins and the NAACP, he was also perceived as a personal threat by this tradtion-bound leader of the NBC." He also quotes Al Duckett who commented that Wilkins was "almost as psychotic about Martin as J.H.Jackson." With King in Chicago, Jackson made frequent allusions to him in his anti-civil rights and his later anti-peace demonstration speeches, though careful not to make specific references. Jackson announced that Chicago did not need any help from outsiders when, to howls of derision from activists, he claimed there were such "truehearted friends of black people as Richard J.Daley and Benjamin C.Willis held important public posts." Jackson's longtime standing in Chicago, and the associations and contacts that he had acquired began very suddenly to jar with the new wave of black activism. ${ }^{26}$

The ever present possibility was that Jackson's position could be exploited. An eminent black church leader speaking for a large local constituency with national repercussions, Jackson's 'anti civil rights' statements made for useful evidence of indigenous opposition to King. His critique of civil disobedience being "not far removed from open crime" fitted neatly within the dominant law and order agenda, helping to discredit King and his troops. Activists would be deeply hurt by statements that claimed that "this campaign of non-violence helped to create tensions and, after these tensions, came violence." ${ }^{27}$ Jackson's faith in the infrastructure and gradual democratic process represented not only a traditional strategy within black protest thought, but in this environment it gave ammunition to the administration's efforts to re-appropriate the symbols of patriotism from the Civil Rights Movement, to counteract King's consciencetugging patriotism with a 'safer' and more familiar black patriotism. Jackson was sixtysix years old and representative of a popular philosophy within previous generations of black leaders that revolved around a strong belief in self-help, taking advantage of disadvantage, capitalising on opportunities within the existing system and instinctively avoiding overt direct action.

17 Jackson declared on the fourth of July, 1966, that "direct action should not be substituted for the federal Constitution or the laws of the land." ${ }^{28}$ Civil disobedience actually "violates the citizens' pledge of loyalty to the American way of life including the way of correcting errors as well as the way of sustaining the democratic principle of the nation." ${ }^{29}$ For Jackson, correction of faults - the elimination of inequality - had to come through commitment to, and confidence in, the existing system, a belief that the structure was inherently capable of resolving problems. By championing this, Jackson undercut King's moral appeal to the American creed and its associated legitimacy. His antipathy toward King and his anti-protest comments picked up on by the press contributed to significant opposition to the civil rights leader. Much of King's success had its roots in his appeal to ideas of America, values he argued had often been overshadowed, but his brand of patriotism was now countered by a second interpretation of patriotism within black communities. King's collectivist faith that was influenced by progressive liberalism was faced with a patriotism that was popular in predominantly older and more conservative black circles, featuring self-help and 
observance of the law. It also represented a confrontation that was part of a larger struggle between King's patriotism and an 'official', state patriotism that was heavily sponsored by local and national government.

Jackson's conservative patriotism was used by himself and by the city to discredit King as a radical who was irresponsible and explicitly unpatriotic. For example, Robert Brisco, the head of the League of Labor and Education called upon all Chicagoans to "shun non-violence as a civil rights tactic...We are asking all citizens of Chicago not to endorse the non-violent organisations that actually bring such violent results as those of Dr. Martin Luther King to this city. The people of the League of Labor and Education appeal to all persons to throw their support behind Dr. J.H.Jackson." ${ }^{30}$ Inevitably, questions over King's representativeness were raised, certainly in relation to Jackson's substantial constituency. Brisco continued that the SCLC and the CCCO (Coordinating Council of Community Organisations, a civil rights umbrella group that had been operating before King arrived, under the leadership of Al Raby) had "thrown a smokescreen around the rights issue" and had "proceeded to mislead Chicago's Negroes." On the issue of King's suitability as leader, he claimed that he would preach "anti-Kingism in street corners if necessary" and appealed to Mayor Daley to "come out and talk to the common man in Chicago, the real grassroots people. He will find that the grassroots people do not support Dr.King." ${ }^{31}$

King had in fact criticised the growing group around Jackson a few months previously, claiming that "I don't think Mr.Jackson speaks for 1\% of the Negroes in this country." Nevertheless, it was a worrying trend that Jackson was becoming increasingly oppositional and that more explicitly, his more conservative patriotism was emerging as a magnet for those opposed to King's activism in the city and a platform from which to launch attacks on King's status as outsider and agitator. ${ }^{32}$

Jackson was clearly opposed to the exuberance of the civil rights movement as well as having personal problems with King, and whilst Chicago was an important stage on which much of their conflict played out, to reduce his role to a predominantly reactive figure is to do his own sophisticated philosophy injustice. In the context of patriotism, his philosophy sits at interesting levels and degrees of contrast to King's. Much of the tension stems from Jackson's own patriotism that bears resemblance to King's, but is received and comprehended from a differing historical and ideological frame of reference.

\section{Missions of Patriotism}

It is Jackson's failure to perceive the Civil Rights Movement at its own patriotic level, seeing it more instantly as a disruptive, harmful and unlawful protest movement rather than a moralistic or Constitutional movement that precluded any accumulation of common ground in their shared desire for black progress. At the annual conclave of the Beta Sigma fraternity in Dallas in late 1957, Jackson delivered a speech that drew attention, as King often did, to the gap between the American promise of equality and the reality. In a statement and plea that echoes King's first public speech at the start of the Montgomery bus boycott at Holt street church in 1955, he started by declaring that "America must not continue to vacillate between her Constitutional concept of democracy and the tradition and practice of segregation and discrimination. If the federal Constitution is impractical...we should rewrite it." ${ }^{33}$ 
King had, in a similar spirit, said to the Montgomery bus boycotters that "if we are wrong, the Constitution of the United States is wrong." ${ }^{34}$ Clearly, Jackson is aware of the discrepancy between national promise and practice, and as an intensely optimistic patriot, he believed in the deliverance of the promise. When defining the civil rights struggle in 1964, Jackson called it a struggle "to fully implement the Federal Constitution" and "a struggle to bring from paper the lofty ideals of America, and apply them in practice to the lives and actions of all Americans." ${ }^{35}$ King had, similarly, declared in Montgomery 1955 that "we are determined to apply our citizenship to the fullness of its meaning. We are here also because of our love for democracy... and because of our deep-seated belief that democracy transformed from thin paper to thick action is the greatest form of government on earth." ${ }^{36}$ And in 1962, King stated that "we are simply seeking to bring into full realization the American dream - a dream yet unfulfilled." ${ }^{37}$ It is the deliverance and implementation of the promise that sets Jackson apart. His own patriotism and his desire to see the Constitutional promises kept is clearly shared with King's patriotism, but it is his perception of where the initiative should come from and whose responsibility it was that defined his difference.

At a Mississppi Convention in 1963 Jackson outlined the fight for "first class citizenship...the rights of all Americans as implied in the Preamble to the United States of American Constitution, as stated in the Pledge of Allegiance to the United States of America and as guaranteed under the Constitution of the United States of America." ${ }_{38}$ He repeatedly spoke, at various points, on the same theme. In Detroit, 1964, he declared that "this is a struggle to adopt in practice as well as theory the concept of man on which the Declaration of Independence is based, and to fully implement the Federal Constitution, one of the greatest documents for human freedom since the writing of the Magna Carta." ${ }^{39}$ In 1966, speaking in the face of the worrying trend as he perceived, away from law and order and toward violent protest and riots, he again referred back to his own vision of patriotism as a touchstone: "We call upon all Americans to dedicate and rededicate themselves to the supreme law of this land, the American ideals of freedom and democracy, and to do it now without compromise or delay." ${ }^{40}$ Protest was both philosophically and strategically wrong, and only patient investment in the system would reap eventual rewards. "The progress of the race lies not in continued street demonstrations" Jackson argued, "and the liberation of an oppressed people shall not come by acts of revenge and retaliation but by the constructive use of all available opportunities and a creative expansion of the circumstances of the past into stepping stones to higher things." ${ }^{41}$

Taking advantage of disadvantage (again reminiscent of Booker T.Washington) led Jackson to harbour suspicions of the Black Power movement too, which detached itself from the progress-through-patriotism approach of the civil rights movement to the extent that he said it showed "no respect for the good that has been realised in American history." ${ }^{2}$ Marking his departure from the civil rights movement's reform patriotism was, firstly, his absolute faith in the power structure bearing responsibility for properly applying the Constitution, a process that must be supported through law and order. His patriotism and his roadmap for progress were glued to the system, and there was no recognition that challenging the status quo could be anything other than unpatriotic. "In our struggle for civil rights we must remain always in the mainstream of American democracy. Our cause must never be divorced from the American cause, and our struggle must not be separated from the American struggle. We must stick to 
law and order, for as I have said in the past I say now, there are no problems in American life that cannot be solved through commitment to the highest laws of our land and in obedience to the American philosophy and way of life. In spite of criticisms and not-with-standing threats and open attacks, I have not retreated from this position and never will as long as America is the America of the Federal Constitution and a land of due process of law." In addition to his philosophical advocacy of this position, he also believed it was a matter of pragmatism and practicality. "We cannot win our battle through force and unreasonable intimidation. As a minority group we cannot win outside of the protection and power of the just laws of this land...The hope of the minority struggle is with the just laws of the land and the moral and constructive forces that are germane to this nation's life and character." ${ }^{43}$ Speaking a year after the Birmingham campaign in Alabama that was ultimately successful in stirring results, it had also threatened riots. Jackson remarked, in language that came close to specifically identifying King, that "the methods that we employ in the present struggle must not lead us into open opposition to the laws of the land. In some cases the technique of direct action and demonstrations have led to mob violence and to vandalism. At least some who have desired to practice these negative methods have used the technique of so-called direct action." ${ }^{44}$ The second feature marking his departure from a reform patriotism is his belief in African-American responsibility for capitalising on opportunities. Rather than it being a duty of the state to deliver equality as a matter of right and justice, Jackson posed the question "What is this struggle for civil rights?" and answered that "it is an effort of American citizens to get full equality of opportunity"45

In his Dallas address he went on to state that "there is a danger that we as a race might stand still while America otherwise grows in democracy. We might become so dedicated to the philosophy of protest that we overlook the chance to invest the opportunities and use the freedoms creatively. The NAACP can create the opportunities for the advancement of colored people but cannot advance them - advancement is a personal responsibility - for citizens must do it themselves. The cultural organisations of this country may open the doors for us but we by choice and initiative walk in. In reality, the NAACP should be called the NACOACP, that is the National Association for the Creating of Opportunity for the Advancement of Colored People. We will strengthen the hands of our leaders as we individually and collectively more and more seize the opportunities won and use wisely the freedoms already acquired." 46

The fundamental differences between the two men's application of patriotism are that he claims advancement is very much a "personal responsibility", that progress is achieved through seizing opportunity within the existing system, and the assumption that there were fewer societal obstacles such as racism and discrimination that restricted these opportunities. ${ }^{47}$ King's patriotism perceived advancement as not just a collective act amongst African-Americans but as the collective, moral responsibility of the nation to include blacks within the creed without having to prove their worth to do so, that it was "a matter of right rather than as a favor to be granted them as though they were aliens seeking naturalization." Jackson's view of opportunity and emphasis on personal achievement and advancement displayed his similarity with the individualisitic 'bootstraps' view of patriotism. It was a black patriotism that followed King's patriotism's recognition of an existing national shortfall but fought for inclusion and better terms in the status quo. Crucially, Jackson's civil rights struggle would be 
waged through the consensually patriotic system of toil and opportunity; his patriotism informed the means by which progress would be achieved. ${ }^{48}$

It was a strange synthesis of King's collective patriotism and a consensual, individualistic patriotism. It was calling loudly for an alternative, but is at the same time calling for it to be realised through the constructed consensus of the American creed, through opportunism. In an article about Jackson in 1960, the Christian Science Monitor reveals more of his philosophy on the creed and gives further insight into his concept of responsibility and his own personal negotiation with a collective patriotism. Whereas King's patriotism saw the racial situation as a result of the country's collective moral irresponsibility and racism over the application of the nation's principles to all Americans, Jackson instead claims that "racial troubles are not indicative of the soul of the nation" and that they "are simply manifestations of people who have elected to sin against the principles of the republic." It was a temporary aberration, and not a systemic problem. "We believe that our leaders, our organizations, and our press should more and more recognize the presence and the position of a vast number of white people who are dedicated to the laws of the land, who are ashamed of the sin, being committed against the soul of the nation, who are working for the growth of democracy and who are SUFFERING for the fulfilment of America's dream of freedom." ${ }^{49}$

Jackson thus perceived the King-led assault on the conscience of America as illconceived, mis-focused, and one that would lead only to a backlash of opinion. Indeed, as Peter Paris suggests, Jackson felt those who "persist in describing the manifold brutalities and hatreds visited upon Black people do, in his opinion, become hindrances to the loftier aspirations of national unity and belonging, goodwill, and cooperation." 50 Consequently, King's efforts, which raised the emotive concept of American hypocrisy, and that sought a shift away from a conservative patriotic faith to a patriotism that actively sought to see its more collectivist philosophy translated into societal reform, were left unacknowledged whilst attempts to alter the entire societal consensus were rebuffed. What King and a collective patriotism perceived as an expansion of the tenets of the Constitution, Jackson saw as a violation. Jackson fought to have the difference between promise and practice made up within the existing system, putting faith in it, making opportunities work, being patient with its sluggishness, but optimistic due to its greater virtues. Jackson's essential optimism and lack of criticism for the existing social structure led to a philosophy characterised by "his consistent praise for the goodness of America and ... his fervent desire for the preservation of national unity .... While Jackson calls on Blacks to engage in self-development for the sake of themselves and the nation, King called upon them to demonstrate the hypocritical nature of America's racism by nonviolent resistance to these structures that prohibit Black participation." Paris concludes that Jackson's principle of social change is "aimed at Black themselves" whilst King's aims to transform society. ${ }^{51}$ King, however, began to question whether any genuine progressive reform could be realised within a society so dominated by an individualistic approach and framed by a conservative consensual creed. King's later, more radical, philosophy affirmed his progressive patriotism, a belief that society's values had to be fundamentally altered, and the moral centre had to be re-orientated before a more collectivist reading could be naturalised and adopted as the new national consensus. 

collective patriotism and crossed racial barriers into matters of class and interracial solidarity, still drew from the Constitutional inheritance of equal humanity for all, but Jackson was suspicious of King's progressivism, referring darkly to "gestures and movements which in many instances have become anti-American, anti-Federal Constitution, and anti-our philosophy of freedom." ${ }^{52}$ The National Baptist Convention "wanted to work for civil rights" as well, wrote Jackson. The crucial difference was that "they wanted to work through the legitimate and prescribed channels of the United States of America." He claims that the NBC was in "the thick of the struggle" from the mid-50s onwards and that they had "taken the position that the Federal Constitution, the supreme law of the land" was "a sufficient guide for building a democratic society." The distinction between Jackson's acceptance of the consensual interpretation of the creed and the way in which he applied his patriotism to protest, and King's application of patriotism, is made all the sharper. ${ }^{53}$

Whilst it can be clearly argued that King's collective patriotism and its moral probing of the Constitution was successful with 1964 and 1965 acts of legislation, Jackson also claimed that black patriotism within the consensus had won similar gains. Jackson's comments on the NBC's own activities and on the nature of civil rights form a crucial philosophical position that critiques the Civil Rights Movement and its relationship with patriotism. "I organized," Jackson wrote, "what became historically known as the 'Urge Congress Movement.' We met as the Olivet Baptist Church in Chicago. Thousands of citizens gathered" and the result was that "one historian stated that without the 'Urge Congress Movement' the 1957 Civil Rights Act never would have passed Congress... we were a part of a democratic turn in history. This was done without bitterness, without threats or intimidation, but with a direct appeal to the spirit of patriotism and to the American way of life, based on the validity and the strength and the promise of the Federal Constitution." This, Jackson claimed, "laid well the foundation and paved the way for what transpired in 1960, 1963 and then in 1964."'The true drive for civil rights in the United States of America need not be revolutionary in character but evolutionary, for it is not against, but in harmony with the Federal Constitution and supported by the American promise and philosophy of democracy." By clear inference, Jackson regarded the Civil Rights Movement as revolutionary, one that was not at all in harmony with the Constitution and a movement that was not even cognisant of the potential value of harnessing the American promise. He assumed that given the institutional embodiment of American democracy, civil rights progress would simply evolve through good government and legally sanctioned forms of 'encouragement' from responsible African-American leaders. King's reformist patriotic vision was once again viewed by Jackson as positively anti-American, and as Paris writes, protesters were thought not to "believe in the lofty principles on which this nation is built." Furthermore, their action actually "implies a repudiation of the federal Constitution and the substance of the American way of life" and again he argued that black protests in fact became "hindrances to the loftier aspirations of national unity and belonging, goodwill and cooperation." Jackson even went on to appropriate "we will overcome" to support his gradualist position: "We will overcome some day because truth will overcome error... and America will overcome all those forces that have hindered and are now hindering the upward thrust of a more perfect democracy." ${ }^{44}$ 
31 Turning King's collective patriotism on its head, Jackson then suggests that "any citizen of Chicago who loves his community and loves and respects the use of the ballot and who had confidence in the Constitution of the United States of America will have no regrets in knowing that such a campaign (much of the Chicago campaign revolved around housing desegregation, 'open housing') had failed in a city of this magnitude and strength." He went on to advise that "with the failing of the campaign of 1966, civil rights groups must more and more wage the battles for freedom where they should be fought, on the legal soils of the nation and on the terrain of goodwill and the protective guidance of the Constitution of the United States and the courts of the land." Once again, Jackson saw a natural link between the enactment of the Constitution and successive administrations, and no element of institutional-ideological tampering with the meanings that were drawn from the document itself. Jackson's comments would be used as part of the city's law and order response to the Civil Rights Movement that fought to reappropriate popular meanings of the Constitution, and to prize the civil rights movement apart from its own patriotism as part of its effort to re-establish control over the political use of the American creed. ${ }^{55}$ Jackson did not perceive the collective, reformist patriotic movement because his own philosophy had negotiated with, and adjusted itself to, the consensual patriotism and American creed that had been made normative. He consequently regarded the Constitution as objective, to be mobilised within that system, rather than recognising the document and the creed as subjective and open to far more progressive interpretation.

This goes a long way to explaining his opposition to demonstrations, particularly the open-housing marches, claiming they were unnecessary because Chicago (and the federal government) already did all it could to embody the 'objective' Constitution. In July 1963, for example, following intensive marching in Alabama, Jackson called for a 60-day moratorium as further demonstrations, he believed, would "only embarrass the President and Congressmen." ${ }^{56}$ In the previous November he had said that "we must move by the law of the land. When we have laws unto ourselves we have to grant our opponent that same right. It is better to take the course of law rather than to take the law into our own hands." ${ }^{57}$

SCLC's Operation Breadbasket campaign, an economic programme run by Jesse Jackson, would thus be considered unnecessary as "there was already in operation a committee called 'The Merit Employment Committee." He railed against the open-housing marches in 1966 because of the way in which "out of town preachers" had come to "invade a town and seek to dictate to the City Council" in what amounted to a "rule of law." The summit agreement that Mayor Daley and other civic leaders signed with King in August 1966 that addressed open housing, "amounted to nothing more than intentions that had already been set by the enlightened statesmen and leaders of the City of Chicago." Their "demands - not requests" that King had symbolically nailed to the door of City Hall had been "dictatorial" and "would put an end to government of the people, by the people and for the people" as it would have placed power in the hands of civil rights leaders rather than government officials. Three and a half million citizens would have been deprived of any say in how problems would be resolved, and he claimed that the small band of unrepresentative civil rights workers "attempted to sanction a method... that the whole city of Chicago would have condemned and disapproved" given the chance. ${ }^{58}$ Jackson's conclusion was to theorise that had the movement in Chicago not "failed ... every other Northern city as well as the nation 
itself would have been confronted with serious obstacles and drawbacks ... the leadership of this city would have shifted from the Mayor and the City Council to the hands of visiting diplomats who have not been selected or chosen by the votes of the citizens of this city... anarchy would have been the watchword in our American cities." He went as far as predicting that activists might become "a dangerous fifth column that could usurp the rights of the local democratic community."

In a broadside against the entire movement, he declared that "campaigns of nonviolence that are easily converted into violence cannot be the answer for the vexing problems of human relations in any city of the United States of America." ${ }^{59}$ Jackson drew a link, for example, between the presence of civil rights activists and the outbreak of rioting in the city in July 1966 . For Jackson, the system was self-correcting, and the more King turned to direct action and demonstrations, the more the situation was inflamed and polarised. Jackson did not perceive King or the Civil Rights Movement as being patriotic in liberating or unlocking another set of values dormant in the American creed but as a failure. His misunderstanding of King and his own patriotism is picked up on by civil rights activist Wyatt Walker following Jackson's 'protest to production' speech. On a speech that reminded many of Booker T. Washington, Walker pointed out, "how can the Negro produce anything when he is deprived of the instruments?" Jackson had given his "Production statement, "we should go on to production" at the National Baptist Convention in September 1961 and was heavily criticised by Walker for being "out of touch" with the prevailing mood and for failing to realise that "picketing, boycotting and peaceful demonstrations against injustice are part and parcel of the Bill of Rights and the Constitution of the United States." ${ }^{60}$

\section{Conclusion}

King's patriotism appealed to the conscience of the nation to uncover and collectively re-emphasise the more universal and liberating themes in the Constitution and Declaration of Independence. Those themes would then form the new conceptual framework for national progress in race relations as well as other national issues including gender, class and military policy. Reform patriotism had to be translated into reform politics. Jackson's patriotism did not urge so much a re-prioritising of the nation's values as a universal loyalty to the system already in place, one that had the ability to recalibrate and self-correct but needed loyalty and patience to reap the benefits. In the late 1960s, Jackson concentrated his philosophy in calling for a 'militant patriotism.' He explicitly argued in 1968 that problems should be solved by the law of the land, people's goodwill, and in an intriguing play on King's patriotism, he suggested that difficulties should be resolved through the moral force of the Constitution and the American philosophy of freedom - there should be an "unquestionable loyalty" to America. As Paris points out, "he preached that every citizen should have faith in the legal machinery of the nation and in the justice set forth so prominently in the federal Constitution." 61

36 It is the predication of philosophy on patriotism and the Constitution that united Martin Luther King and Joseph Jackson. For both men, the Constitution inherently possessed the means to create a more perfect union, and the application of patriotism shaped their philosophy of protest. Jackson urged blacks to "submit themselves to the merit system", play by the rules, take advantage of opportunities, and this conservative 
patriotism was countered by King, whose patriotism was reflected in protest that encouraged the nation to realign priorities from individualism to collectivism. ${ }^{62}$ As Jackson's 'militant' patriotism advanced in the mid-late 1960s, so King's patriotism also advanced, with his critique on the Vietnam war in April 1967 in which he declared that America required a radical restructuring of its values, and that he spoke out because he loved America. His defence of this position can be transferred to the entire philosophical struggle with Jackson, when he talked about those who would "equate dissent with disloyalty." ${ }^{63}$

Whilst King used patriotism to appeal for a new sense of patriotism, Jackson used patriotism to shore up the system as he believed all its necessary principles were embodied within state and national government. Jackson was a gradualist of the old school. The problems faced by society were a result in the time-lag between the evolutionary nature of American democracy and constitutional law and the realisation of full constitutional citizenship. Jackson pointed out that he believed in the promise of American democracy and the potential for black equality "that gradually has been honored and that will be more completely fulfilled in due time." ${ }^{64}$ Consequently, he believed the present machinery was sufficient to realise equality through legal means and did not believe agitation in any form would be beneficial, quite the opposite. "Patience has allowed the evolution of democratic government to correct its mistakes." ${ }^{65}$ African-Americans should therefore make use of opportunities that were in place and which would be expanded in due time. "The progress of the race lies not in continued street demonstrations, and the liberation of an oppressed people shall not come by acts of revenge and retaliation but by the constructive use of all available opportunities and a creative expansion of the circumstances of the past into stepping stones to higher things." ${ }^{66}$ The constructive use of opportunities signalled, ultimately, Jackson's place within the consensual framework of patriotism and progress as it was urging African-Americans to play the game of an ethnicised dream by the rules.

The 'problems' that have arisen previously with Jackson have inevitably revolved around his advocacy of law and order, responsibility, refraining from counterproductive marching, his association with the Chicago machine and his linked comments in praise of Mayor Daley. This often aided the power structure in its attempts to de-legitimise King and the movement by upholding a respectable and conservative alternative, consolidated by Jackson's personal feelings toward King.

Jackson was to prove useful to those preserving the individualistic American creed and to advocates of law and order who called for protests to move from the streets to the negotiating tables and law courts. He urged protesters to be obedient to the law of the land and perceived black and white equality as an evolutionary process in which those who obstructed the impetus were anti-American. Jackson believed in the promise inherent in the Constitution and stored faith in the fulfilment of it through time. "Although the law is not an agency for moral reform" writes Paris, "Jackson contends that the just laws of the land must always determine the context in which civil rights struggles are to be waged. In this respect the law must always be obeyed." ${ }^{67}$ Younger civil rights groups such as SCLC and SNCC must, Jackson suggested, "be evaluated not only in the light of their enthusiasm but in the light of long-range goals, practical achievements, and their constructive relationship to the Federal Constitution and the American way of life." ${ }^{68}$ Measured against an American way that had been 
consensualised by the power structure as individualistic, the movement's activities would consistently appear marginal at best and un-American at worst.

It is ultimately ironic that like King he stored so much belief in the founding documents and their whispers of equality, but unlike King who perceived them as liberating documents that should be made to lean hard upon the nation's morals, Jackson was somewhat constricted by his faith in the Constitution, believing that patience and faith would see the fulfilment of promises through the workings of a just system. It was the existing system, one that historically had much to gain from maintaining certain sets of racial and ethnic characteristics, that Jackson ended up being complicit in preserving. Alternatively, King brought a patriotism to bear that unlocked the official, individualistic, narrative of patriotism and aired a more collectivist reading. In trying to present the public with often visual examples of inequality to arouse the conscience, the tactics were depicted as being on the edge of being disorderly and unlawful. One of the most damaging critiques of King's protest was that it was unpatriotic, as so much success had stemmed from drawing upon the American creed for legitimacy and strength. King's patriotism was a challenge to the consensual patriotism of the country, to liberate the best in the American creed and save the soul of America. Jackson's patriotism was pragmatic and conservative, a belief that the meanings within the Constitution and the American creed shouldn't be wrestled with, they should simply be respected and adhered to, and that all protest energies should be channelled through the existing system.

"For Jackson, the unification of all American people around the basic principles of American government assured the eventual attainment of African American civil rights." ${ }^{69}$ But the same is true for Martin Luther King. Whilst Jackson was concerned that King wandered away from a monolithic Constitution and was flirting with civil disobedience and law and disorder, King was simply interpreting the Constitution and creed with the language and philosophy drawn from another tradition. Conservative black patriotism, Jackson's chosen strategy for racial progress, refused to recognise the Americanness of King's own patriotic strategy, and their protracted decade long struggle transcends the simplistic conservative versus progressive label that has so often been applied, into a revealing philosophical and conceptual debate.

43 4. E. Franklin Frazier, The Negro Church in America (New York: Schocken Books, 1964), 47-49; Taylor Branch, Parting the Waters: America in the King Years, 1954-1963 (New York: Simon and Schuster, 1988), 56.

\section{NOTES}

1. Michael Eric Dyson, I Might Not Get There With You: The True Martin Luther King, Jr. (New York: Free Press, 2000), 123; David Garrow, Bearing the Cross: Martin Luther King Jr., and the Southern Christian Leadership Conference (New York: Vintage Books, 1988), 165.

2. Ralph Abernathy, And the Walls Came Tumbling Down (New York: HarperCollins, 1991), 171 
3. 'Chicago's “Other” Rev. Jackson,' Chicago Tribune, 11 November 1973; 'Influential Minister Is Honored,' Chicago Tribune, 19 February 1990.

4. The Olivet church had gained much of its strength in the 1910s-20s, receiving thousands of black migrants from the Southern states into its congregation - between 1916-1919 some five thousand people joined the church. In December 1958 his congregation voted that he have life tenure. Other sources place membership at seven million in the late twentieth century, with around 30,000 congregations.

5. Only Peter Paris has written substantially on both men in his book Black Leaders in Conflict wherein he compares the lives of Jackson, King, Malcolm X and Adam Clayton Powell (New York: Pilgrim Press, 1978).

6. Joseph Jackson, 10 September $1964,84^{\text {th }}$ Annual Session of the National Baptist Convention, Detroit, Michigan. Available online: http://teachingamericanhistory.org/library/index.asp? document $=642$

7. Garrow, Bearing, 491.

8. Letter, 5 March 1956, from Jackson to King and the Montgomery Improvement Association, in Clayborne Carson, ed. The Papers of Martin Luther King, Jr.: Birth of a New Age, December 1955December 1956 (Berkeley: University of California Press) 155

9. Branch, Parting The Waters, 56.

10. Wallace C. Smith, 'Progressive National Baptist Convention: The Roots of the Black Church,' American Baptist Quarterly, 19/3 (September 2000): 248.

11. Branch, Parting, 228.

12. Joseph H. Jackson, Unholy Shadows and Freedom's Holy Light (Nashville: Townsend Press, 1967), 118.

13. Branch, 506.

14. Garrow, Bearing, 166; Branch, Parting, 505.

15. Wallace Best, "The Right Achieved and the Wrong Way Conquered": J. H. Jackson, Martin Luther King,Jr., and the Conflict over Civil Rights,' Religion and American Culture: A Journal of Interpretation, 16/2 (Summer 2006): 204.

16. Taylor Branch, Pillar of Fire: America In The King Years, 1963-65 (New York: Touchstone, 1998), 25.

17. Best, The Right Achieved, 196.

18. Branch, Parting, 507.

19. Best, The Right Achieved, 217.

20. Ibid.

21. Abernathy, And the Walls, 172.

22. 'King '66 visit to Chicago not a warm welcome,' Chicago Defender, 19 January 2011.

23. Jackson, Unholy Shadows, 137, 38, 138, 146, 145. Willis in particular was a figure of hate, along with the Board of Education in black Chicago having maintained a system of segregated schools. The indigenous Chicago civil rights groups, under the CCCO, had repeatedly targeted their energies on education and had, in 1963 and 1964, staged city-wide school boycotts. In 1963, 250,000 children attended Freedom Schools for a day. The Silent Six was the name given to Daley's handpicked African-American aldermen who were notorious for their loyalty to the mayor and their silence and inaction on issues concerning civil rights.

24. Ibid., 154.

25. Abernathy, And the Walls, 172

26. Garrow, Bearing, 166, 659 n.37, 491.

27. Jackson, Unholy, 161.

28. Chicago Tribune, 4 July 1966.

29. Jackson, Unholy, vii.

30. Chicago Defender, 13 September 1966.

European journal of American studies, 6-1 | 2011 
31. Ibid.

32. New York Times, 7 July 1966.

33. Jackson at 43rd Annual Conclave of the Phi Beta Sigma fraternity, Dallas, Texas, 29 December 1957, Box 385, Folder 385-6 (Jo Jackson file), Barnett papers, Chicago Historical Society, Chicago (hereafter CHS). Martin Luther King's Holt Street Baptist Church speech from 5 December 1955: "If we are wrong, the Constitution of the United States is wrong" quoted in Carson et al. Eyes on the Prize (New York: Penguin, 1991), 48.

34. King cited in Eyes on the Prize, 50.

35. Jackson, NBC Convention, Detroit, September 1964 (online reference, as note 7).

36. King cited in Eyes on the Prize, 49.

37. King speech at the National Press Club, Washington, D.C., 19 July 1962, cited in James Melvin Washington (ed.), A Testament of Hope: The Essential Writings and Speeches of Martin Luther King, Jr. (San Francisco: HarperCollins, 1986), 100.

38. Mississippi convention, 25 January 1963, Box 385-6, Barnett papers, CHS.

39. Detroit Convention, 10 September 1964 (as note 7).

40. Chicago Defender, 26 July 1966.

41. Detroit Convention, 10 September 1964 (as note 7).

42. Peter Paris, Black Leaders, 67

43. Detroit Convention, 1964 , as note 7

44. Detroit Convention, 1964 , as note 7

45. Ibid.

46. Phi Beta Sigma, Dallas

47. Paris, Black Leaders, 38.

48. Richard King, 'Martin Luther King and the Meaning of Freedom' in Peter J. Albert and Ronald Hoffman (eds.), We Shall Overcome (New York: De Capo, 1993), 142.

49. Christian Science Monitor, 1 March 1960.

50. Paris, Black Leaders, 54

51. Ibid.

52. Jackson, Unholy, 84.

53. Ibid., 119, 84.

54. Ibid., 79, 227, 65, 237.

55. Ibid., 168.

56. Jackson cited in Associated Negro Press, 8 July 1963, Joseph H. Jackson papers, CHS (the archive is as yet not fully processed, so that folder/box numbers are still unavailable).

57. Manuscript, 19 November 1962, Jackson papers, CHS.

58. Jackson, Unholy, 154, 158-162, 167, 160; "In a democratic society, elected officials make requests of their constituents," $155,159$.

59. Ibid., 168, 160, 155, 167, 164.

60. Atlanta Constitution, 15 November 1962.

61. Paris, Black Leaders, 53.

62. Ibid., 62.

63. King, 'A Time to Break Silence,' 4 April 1967

Online: Stanford University Martin Luther King Project:

http://mlkkpp01.stanford.edu/index.php/encyclopedia/documentsentry/doc_beyond_vietnam

64. Christian Science Monitor, 1 March 1960.

65. Ibid.

66. Jackson, Unholy, 199.

67. Paris, Black Leaders, 52.

68. Jackson, Unholy, 227.

69. Best, 209. 


\section{AUTHOR}

\section{SAM HITCHMOUGH}

Department of History and American Studies, Canterbury Christ Church University, Canterbury, Kent 